Научная статья

УДК 37.033

DOI: $10.18101 / 2307-3330-2021-4-10-13$

\title{
ЭКОЛОГИЧЕСКАЯ ГРАМОТНОСТЬ КАК ОСНОВА ГЛОБАЛЬНОЙ ГРАЖДАНСТВЕННОСТИ ЛИЧНОСТИ
}

\section{(C) Бабиков Владимир Александрович}

кандидат географических наук, доцент, Бурятский государственный университет имени Доржи Банзарова Россия, 670000, г. Улан-Удэ, ул. Смолина, 24a mien_bsu@mail.ru

\author{
(C) Маладаева Ольга Климентьевна \\ кандидат географических наук, доцент, \\ Бурятский государственный университет имени Доржи Банзарова \\ Россия, 670000, г. Улан-Удэ, ул. Смолина, 24а \\ maladaeva@bk.ru
}

Аннотация. Авторами в представленной статье рассмотрены вопросы формирования, становления и развития понятия «экологическая грамотность» обучающихся в условиях средних общеобразовательных учреждений. А именно об общих сведениях и понятиях экологической грамотности, о структуре и основных элементах научных определений этого понятия, сведения о разработке и функционировании в современных условиях общеобразовательной школы модели формирования экологической грамотности, также приведены примеры заданий на формирование экологической грамотности, в том числе у младших школьников. Важной задачей современного педагога является формирование и развитие элементов экологической грамотности на разных этапах образовательного процесса. Экологически грамотный человек представляет собой пример будущего гражданина нашей планеты, ориентированного на существование в условиях зеленой экономики, развивающейся на принципах концепции устойчивого развития.

Ключевые слова: экологическая грамотность, экологические знания, устойчивое развитие, экологическая компетентность, метапредметные результаты, исследовательская деятельность.

\section{Для цитирования}

Бабиков В. А., Маладаева О. К. Экологическая грамотность как основа глобальной гражданственности личности // Вестник Бурятского государственного университета. Образование. Личность. Общество. 2021. № 4. С. 10-13.

Под экологической грамотностью прежде всего, понимается способность человека занимать активную гражданскую позицию по вопросам, связанным с естественными науками, и его готовность интересоваться экологическими и естественнонаучными идеями. Экологически грамотный человек стремится участвовать в обсуждении проблем, относящихся к экологическим наукам и технологиям, что требует от него сформированности следующих компетенций:

- научно объяснять природные события и явления;

- понимать смысл и значение основных особенностей естественнонаучного исследования; 
В. А. Бабиков, О. К. Маладаева. Экологическая грамотность как основа глобальной гражданственности личности

- интерпретировать данные и использовать научные доказательства для получения выводов.

Экологическая грамотность - это уровень знаний, умений и навыков, позволяющих осознанно и компетентно участвовать в природоохранной деятельности по предотвращению и устранению ущерба, причиняемого природе деятельностью человека [1].

Во всех этих определениях экологическая грамотность представлена как результат достижения предметных требований к результатам образования [2].

Согласно ФГОС общего образования, при характеристике понятия экологическая грамотность указывается ее осознанность и осмысленность, творческий и метапредметный характер: как «способность оценивать последствия деятельности человека в природе и влияние факторов риска на здоровье человека; выбирать целевые и смысловые установки в своих действиях и поступках по отношению к живой природе, здоровью своему и окружающих, осознавать необходимость действий по сохранению биоразнообразия и природных местообитаний видов растений и животных» [3].

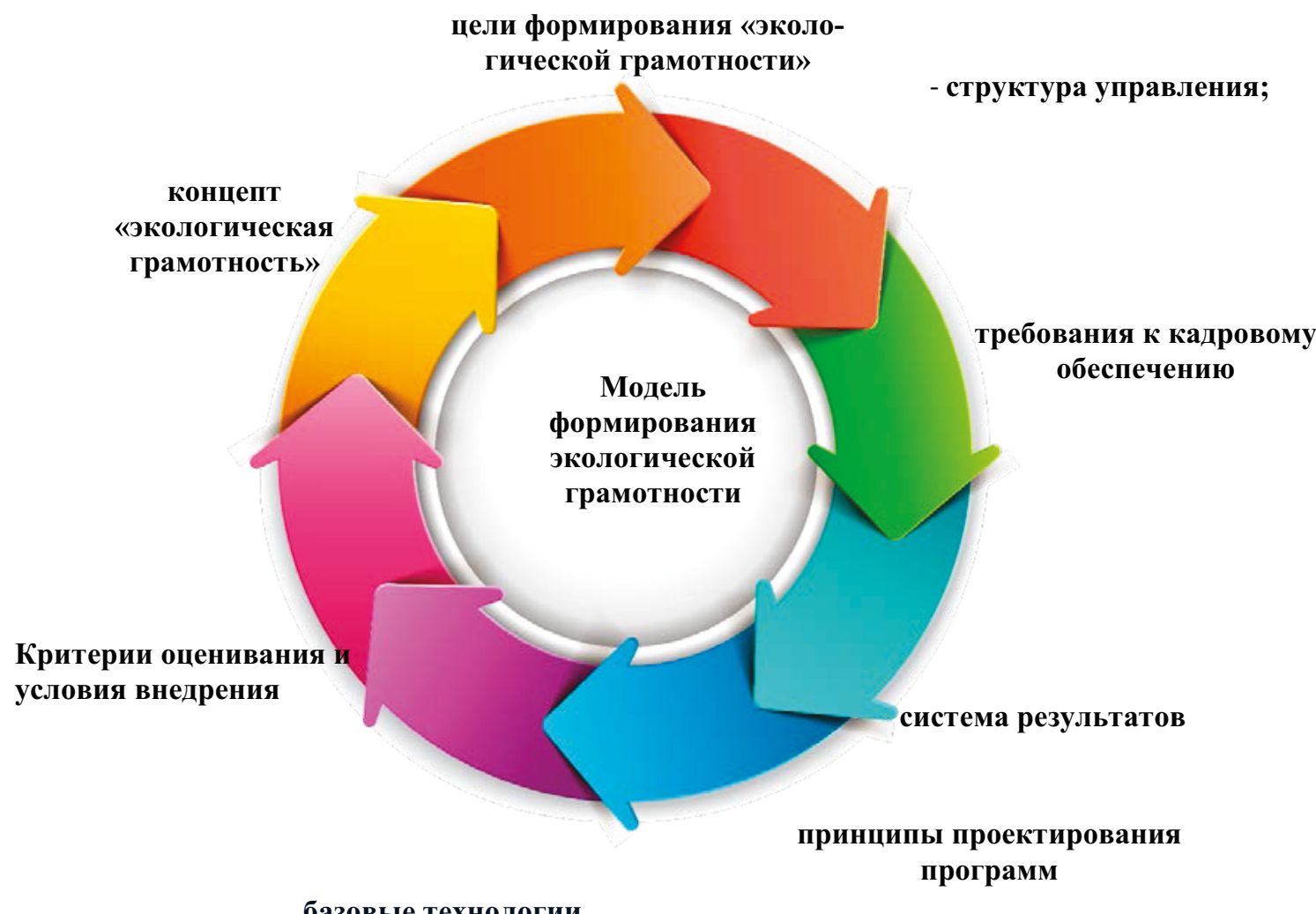

базовые технологии

Рис. 1. Модель формирования экологической грамотности (по материалам М. В. Аргуновой, Д. С. Ермакова, 2014) 
В работе М. В. Аргуновой, Д. С. Ермакова «Социально-педагогические аспекты формирования экологической грамотности» представлена модель основных аспектов и условий формирования экологической грамотности, представленный на рис. 1 [4].

Методологической основой проблемы формирования экологической грамотности выступили работы Н. Ф. Виноградовой, И. Н. Пономаревой, А. Н. Захлебного, И. Д. Зверева, Т. В. Кучер, Б. Т. Лихачева, И. Т. Суравегиной, И. В. Цветковой и др., в них обосновываются теоретические подходы к определению уровня сформированности экологической грамотности школьников.

В качестве основных форм и приемов формирования экологической грамотности могут быть названы следующие: экологические игры, экологические исследовательские практикумы, кейс-задания, экологические квесты, а также организация наблюдений за объектами живой и неживой природы

Примеры заданий на формирование экологической грамотности:

«Живая грязь». После дождя сходи на прогулку в лес. Для прогулки выбери обувь с рифленой подошвой. Придя домой очисти грязь с обуви в специальный контейнер или ящик для выращивания рассады. Поставьте их на солнечное окно и время от времени поливайте. Что происходит в контейнере или ящике для рассады? Как называется этот процесс?

«Лесной алфавит». Давайте найдем ваше имя в природе. Оглянитесь вокруг и постарайтесь найти очертания букв в окружающих вас предметах на каждую букву вашего имени. А еще можно сфотографировать или зарисовать каждую букву и таким образом собрать «природный алфавит».

Таким образом можно констатировать что среди главных педагогических подходов к формированию экологической грамотности следует отнести: обучение через овладение понятиями и принципами («концептуальное обучение»), обучение через исследование, проектное обучение [5].

\section{Литература}

1. Чернухин О. А. Организация исследовательской деятельности школьников естественнонаучной и экологической тематики. Образовательные программы. Новосибирск: Немо-Пресс, 2013. 80 с. Текст: непосредственный.

2. Дзятковская Е. Н. Образование для устойчивого развития в школе. Культурные концепты. «Зеленые аксиомы». Трансдисциплинарность: монография. Москва: Образование и экология, 2015. 328 с. Текст: непосредственный.

3. Леонтович А. В. Исследовательская деятельность учащихся как способ развития субъектной позиции // Исследовательская деятельность учащихся: научно-методический сборник: в 2 т. / под общей редакцией А. С. Обухова. Т. 1. Теория и методика. Москва: Общероссийское общественное движение творческих педагогов «Исследователь», 2007. С. 150-156. Текст: непосредственный.

4. Отношение школьников к природе / под редакцией И. Д. Зверева, И. Т. Суравегиной. Москва: Педагогика, 1999. Текст: непосредственный.

5. Авсейкова В. В., Чеховская Н. В. Мир природы через наблюдения. Мозырь: Белый ветер, 2001. Текст: непосредственный.

Статья поступила в редакиию 02.10.2021; одобрена после рецензирования 13.10.2021; принята к публикации 15.12.2021. 


\section{ENVIRONMENTAL LITERACY AS THE BASIS \\ OF PERSONALITY GLOBAL CITIZENSHIP}

\section{Vladimir A. Babikov}

Candidate of Geographical Sciences, Associate Professor, Banzarov Buryat State University

24a Smolina St., Ulan-Ude, 670000, Russia

mien bsu@mail.ru

Olga K. Maladaeva

Candidate of Geographical Sciences, Associate Professor

Banzarov Buryat State University

24a Smolina St., Ulan-Ude, 670000, Russia

maladaeva@bk.ru

The authors of the article consider the issues of formation and development of "environmental literacy" concept of students in secondary educational institutions, as well as general information about the concept of environmental literacy, its structure and main elements of its scientific definitions; information about the development and functioning of environmental literacy formation model in modern conditions of comprehensive school. It also gives the examples of tasks for the formation of environmental literacy, including primary schoolchildren. Formation and development of environmental literacy elements at different stages of the educational process is an important task of a modern teacher. An environmentally literate person is an example of a future citizen of our planet, focused on living in a green economy developing on the principles of the sustainable development concept.

Keywords: environmental literacy, environmental knowledge, sustainable development, environmental competence, meta-subject results, research activity.

The article was submitted 02.10.2021; approved after reviewing 13.10.2021; accepted for publication 15.12.2021. 